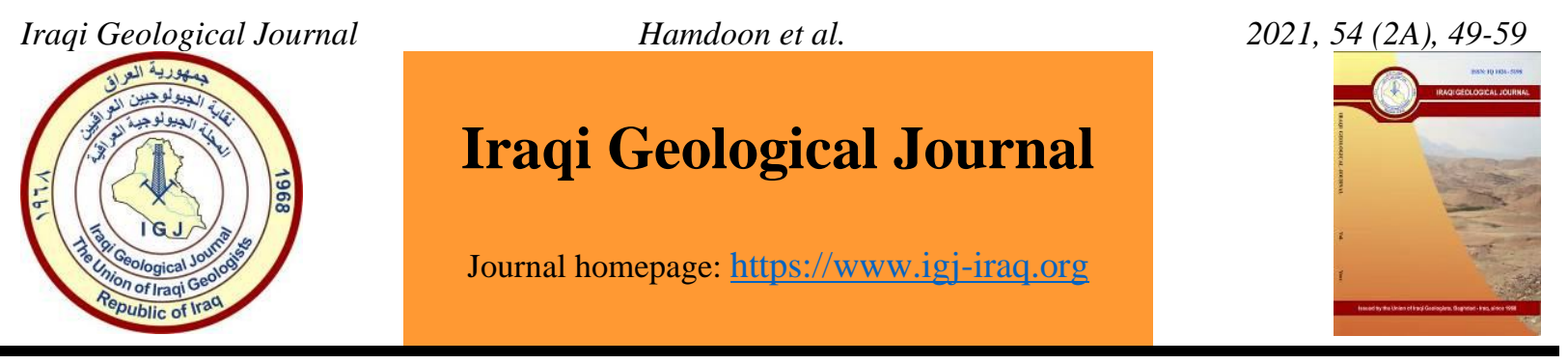

\title{
Structural Analysis and Morphotectonic Interpretation of Ain Sifni Anticline, Northern Iraq
}

\author{
Alaa N. Hamdoon', Rabeea Kh. Znad ${ }^{2}$ and Hadeer Gh. M. Adeeb ${ }^{3, *}$ \\ ${ }^{1}$ Remote Sensing Center, Mosul University, Mosul, Iraq \\ ${ }^{2}$ Dept. of Geology, College of Science, Mosul University, Mosul, Iraq \\ ${ }^{3}$ Dams and Water Resources Research Center, Mosul University, Mosul, Iraq \\ * Correspondence: hadeeradeeb@uomosul.edu.iq
}

Received: 20 August 2020; Accepted: 26 February 2021; Published: 31 July 2021

\begin{abstract}
Ain Sifni anticline is located in northern Iraq within High Folded Zone. It contains some tectonic deformations that need to study to determine the source and mechanism of these deformations concerning the geological setting of the study area. This study includes structural and morphotectonic interpretations for the Ain Sifni anticline, such as the visual \& digital interpretation of satellite images and the Digital Elevation Model interpretation. These parameters are used to identify the morphogenic criteria and subsequently, to conclude a morphotectonic aspect of the deformations in the Ain Sifni anticline. Because of the regional tectonic evolution in this area, the structural and morphotectonic analysis of this anticline shows much evidence of morphological changes at the southeastern plunge area of the anticline within the Injana and Mukdadiya formations in comparison to the northwestern plunge area of the anticline. In addition, two recent water gaps have been recognized at the southeastern plunge area, one is confirmed and the other is proposed, and then a wind gap has been recognized in the middle of the anticline. A relation has been established between these morphotectonic features with the lateral propagation of the anticline towards the southeast, due to the regional tectonic deformation. A significant main fault has also been detected as a dextral strike-slip fault perpendicular to the fold axis of the anticline. This fault caused a difference in the vergency of the anticline and deformed the outcrops of formations in the study region.
\end{abstract}

Keywords: Morphotectonic; Water-gap; Wind-gap; Strike-slip fault; Fold lateral propagation; Ain Sifni

\section{Introduction}

Ain Sifni anticline is one of the geological structures in northern Iraq, bounded from the north by Al-Shaikhan anticline and from the west by Dahqan anticline and from the south by Mahad anticline. The axis of this anticline extends northwest-southeast (Fig. 1). The study area is located near the town of Al-Shaikhan, about $45 \mathrm{~km}$ north of Mosul City and about $35 \mathrm{~km}$ southeast of Duhok City, between the latitudes $36^{\circ} 45^{`} 20^{\prime \prime}-36^{\circ} 38^{`} 50^{\prime \prime}$ and longitude $43^{\circ} 14^{`} 10^{\prime \prime}-43^{\circ} 30^{`} 00^{\prime \prime}$. The total land of the study area occupies of about $115 \mathrm{~km}^{2}$.

The main objective of this study is to find a morphotectonic interpretation of the most prominent evidence found within the Ain Sifni anticline, which will help to understand the tectonic fold growth of

DOI: $10.46717 /$ igj.54.2A.4Ms-2021-07-25 
the anticline. Furthermore, to conduct a structural interpretation based on distinguishing the structural features.

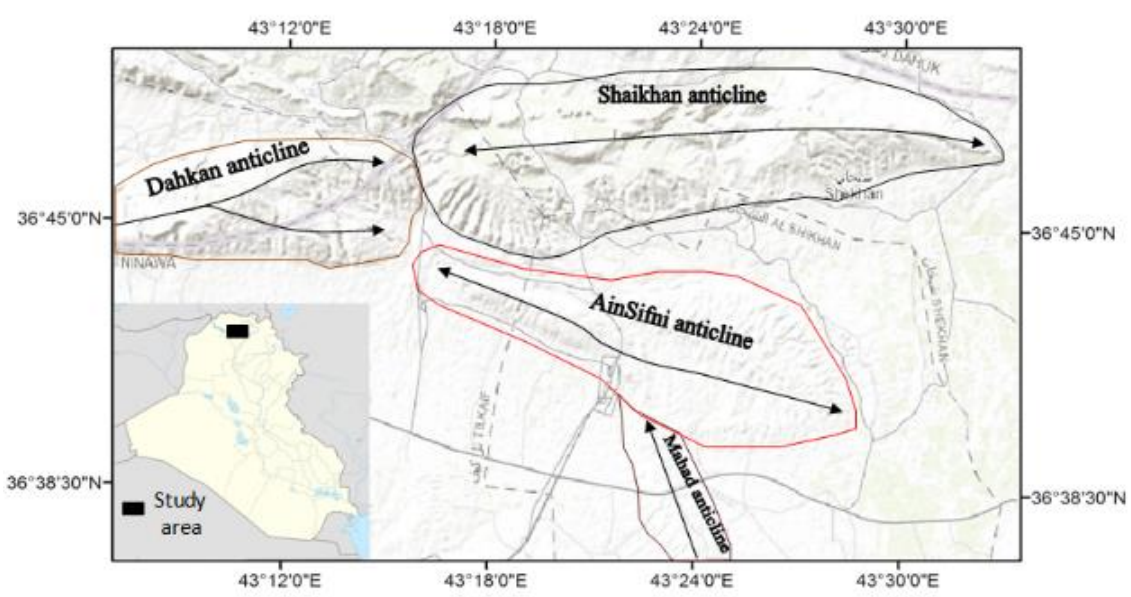

Fig. 1. The satellite image of the study area shows the location of the Ain Sifni anticline

\section{Geology and Tectonic of the Study Area}

Ain Sifni anticline is one of the structures that geologically located on the northern boundary of the Foothill Zone (Jassim and Goff, 2006). The exposed geological units extend in ages from the Middle-Upper Eocene to the Recent (Fig. 2); they are from the oldest Pila Spi, Fat'ha, Injana, Mukdadiya, and BaiHasan formations.

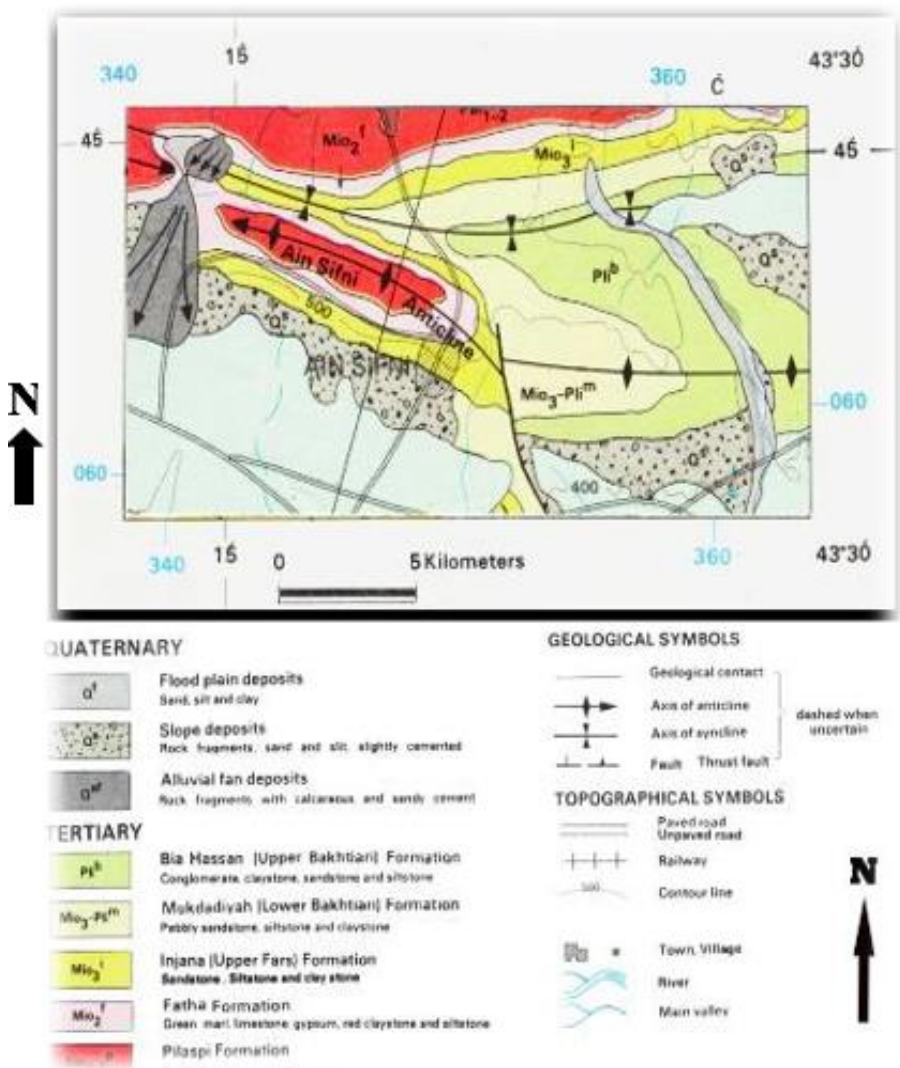

Fig. 2. Geological map of the study area (Geosurv, 1995) 
The hard-competent faulted Pila Spi limestone Formation forms the core of Ain Sifni anticline (Fig. $3 \mathrm{~A})$, whereas the incompetent intensively eroded marls, limestone, and anhydrite sequence, belong to the Fat'ha Formation and form the flanks of the anticline (Figs. 3B and F). However, the Injana Formation can be distinguished in satellite images because it consists of succession layers of sandstone and mudstone (Fig. 3C and D). Such layers form a good environment of differential weathering, lead to creating prominent structural ridges, and can be distinguished in the satellite images. The Mukdadiya Formation in the eastern part of the anticline is largely subjected to erosion, and because of its clastic deposits, it consists of a high percentage of surface drainage patterns. While Bai Hasan Formation forms the outer ridge of the eastern part of the anticline, particularly in the southeastern plunge (Fig. 3E). Tectonically, the study area is situated in the northern part of the Arabian Plate within the Foothill Zone (Jassim and Goff, 2006). It is a far distance from the collision zone of the Arabian Plate with the Eurasian Plate. Mountain building and landscape evolution controlled by the interplay between river dynamics and tectonic forces (Collignon et al., 2016). More specifically,

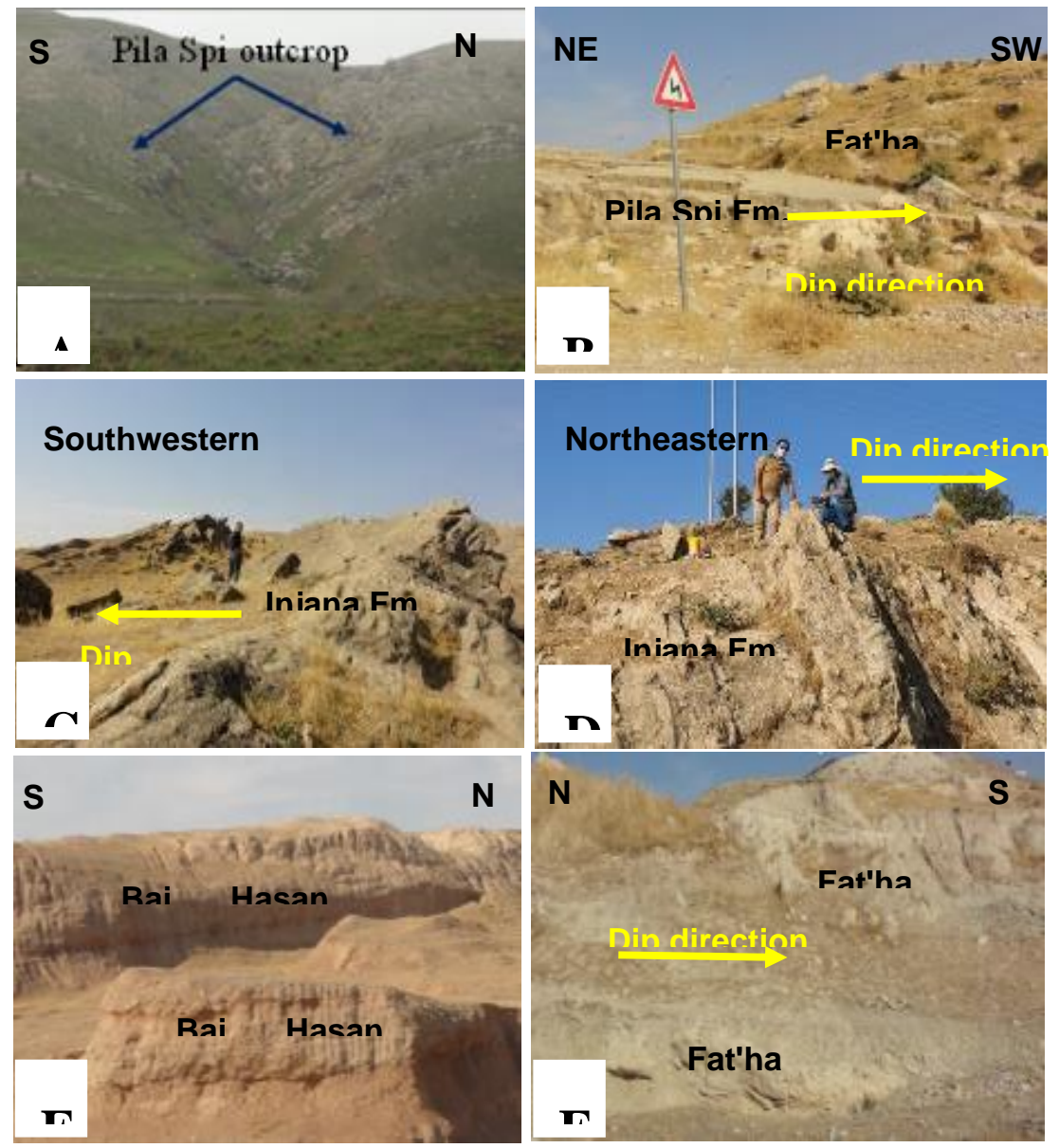

Fig. 3. Outcrops of the geological formations in the study area

Geomorphology and drainage patterns provide indirect information on tectonic activity (Alvarez, 1999; Bretis et al., 2011; Burbank and Pinter, 1999; Burbank and Anderson, 2001; Keller et al., 1999; Tomkin and Braun, 1999; Castelltort and Simpson, 2006; Ramsey et al., 2008; Grasemann and Schmalholz, 2012; Collignon et al., 2016). One of the most recent researches investigating this topic is the study of Sissakian et al. (2020) in Handreen, Zozik, and Tanoun anticlines in Kurdistan Region-Northern Iraq based on the interpretation of the satellite images and locally geological and 
topographic maps. They conducted the lateral growth of these anticlines through different paleo-drainage patterns and current stream activities.

\section{Results}

\section{1. Morphotectonic Interpretation of the Limbs and Plunge Zones of the Anticline}

Satellite images have shown that the form of the drainage pattern prevailing within the Bi Hasan Formation is wider and longer on the northeastern limb of the anticline compared to its southwestern limb, which is shorter and narrower. This is due to the southwestern vergency of the anticline, (i.e. the dip of the layers on the northeastern limb of this part is less than the dip of the layers at the southwestern limb). On the contrary, the widespread drainage patterns within the Pila Spi Formation are longer on the southwestern limb compared to the less long patterns located on the northeastern limb of the anticline. (Fig. 4). Moreover, the flat iron topography, which often refers to the dip direction of the layers (Cotton, 1942) is broader in the northeastern limb near the southeastern plunge area. This usually indicates a slight dipping of the layers on this limb, in comparison to the southwestern limb.

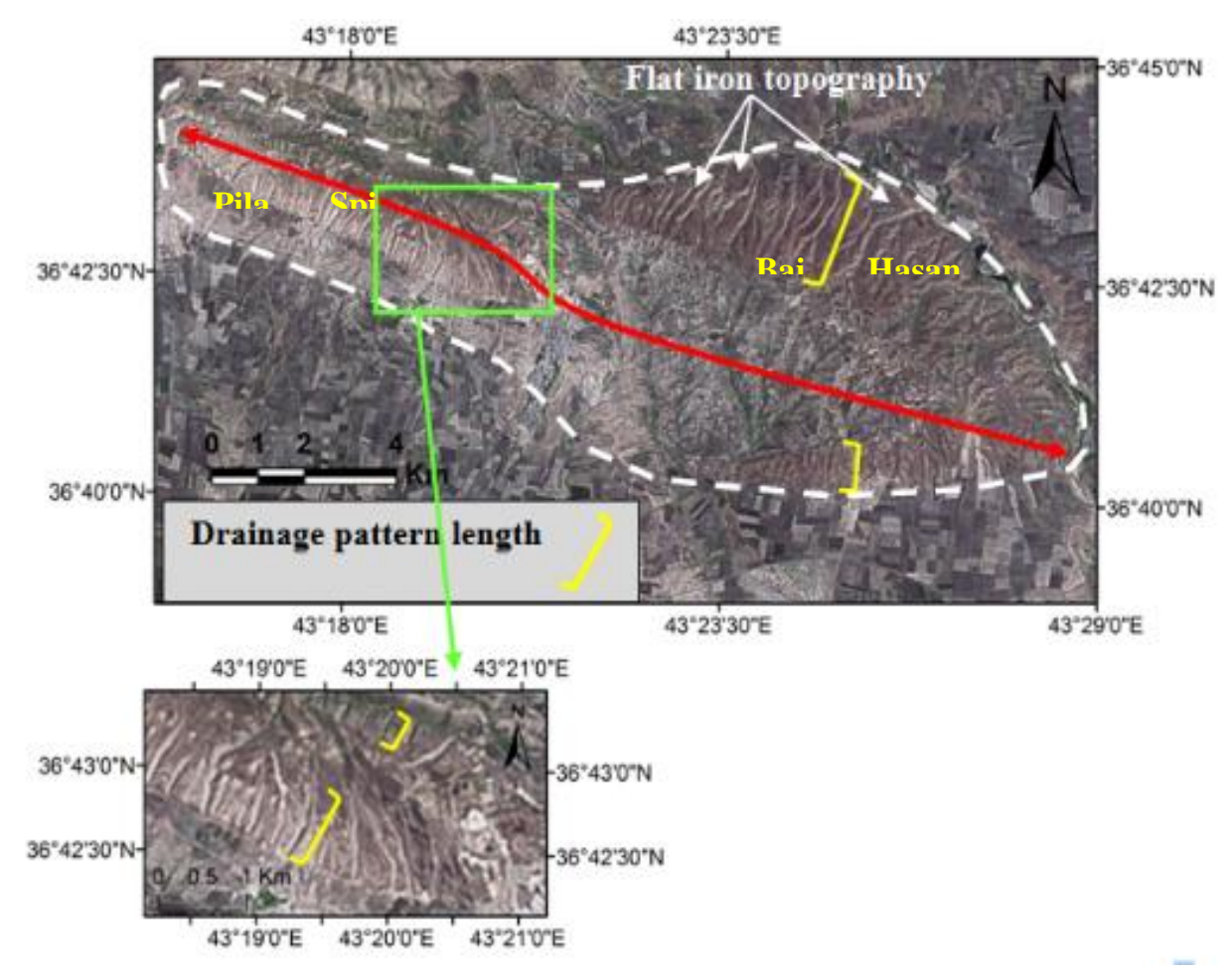

Fig. 4. Effect of the vergency on the length of the drainage pattern in the northeastern and southwestern parts of the Ain Sifni anticline

According to the cross-sections drawn and the stereographic projection, for both parts of the anticline, it reveals that the vergency in the southeastern part of the anticline is towards the southwest, (Fig. 5A), while the vergency in the northwestern part is to the northeast (Fig. 5B). The main geological structure of the anticline has been precisely defined, as well as the identification of the main fault that cuts the southwestern limb of the anticline specifically close to the southeastern plunge (Geosurv, 1995). The general trend of the specified fault extends north northwest-south southeast and sub perpendicular to the folding axis (Fig. 6). The fault runs parallel to the northeastern limb of the anticline clearly from asymmetrical drainage tributaries and inclination of the Injana Formation beds (Fig. 6). Using the data 
from three seismic sections, Al-Kubaisi and Shakir (2018) have concluded that there are several faults to the west of the study area. These faults correspond to the inferred main fault, and that might be assumed that they are the extensions of a major regional fault in the region.
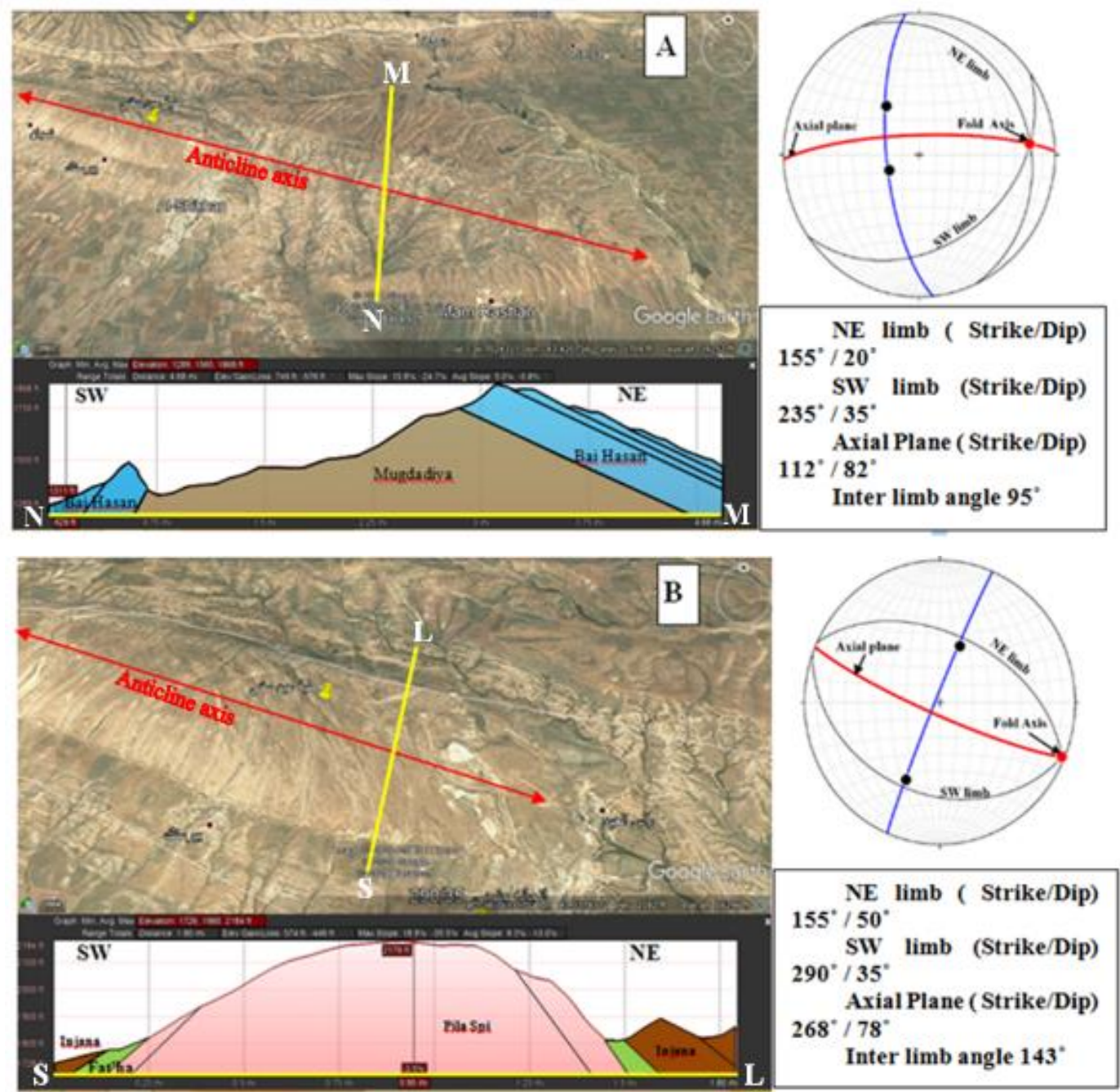

Fig. 5. Cross-section (M-N) \& (L-S) with stereographic projection analysis on the east side (A) and on the west side (B) of the anticline

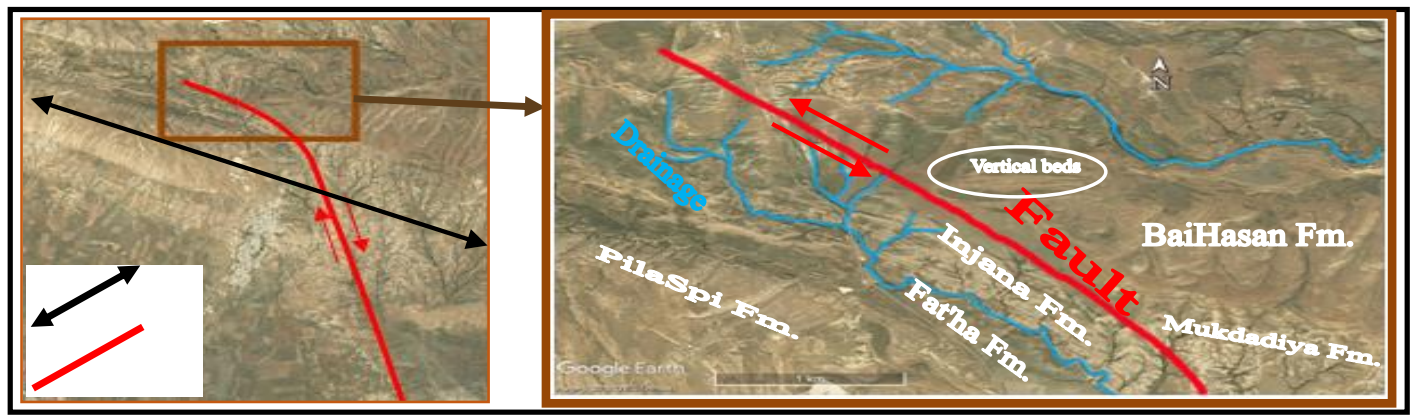

Fig. 6. Effect of the main fault on the northeastern limb of the anticline showing the influence of the layers and drainage pattern 


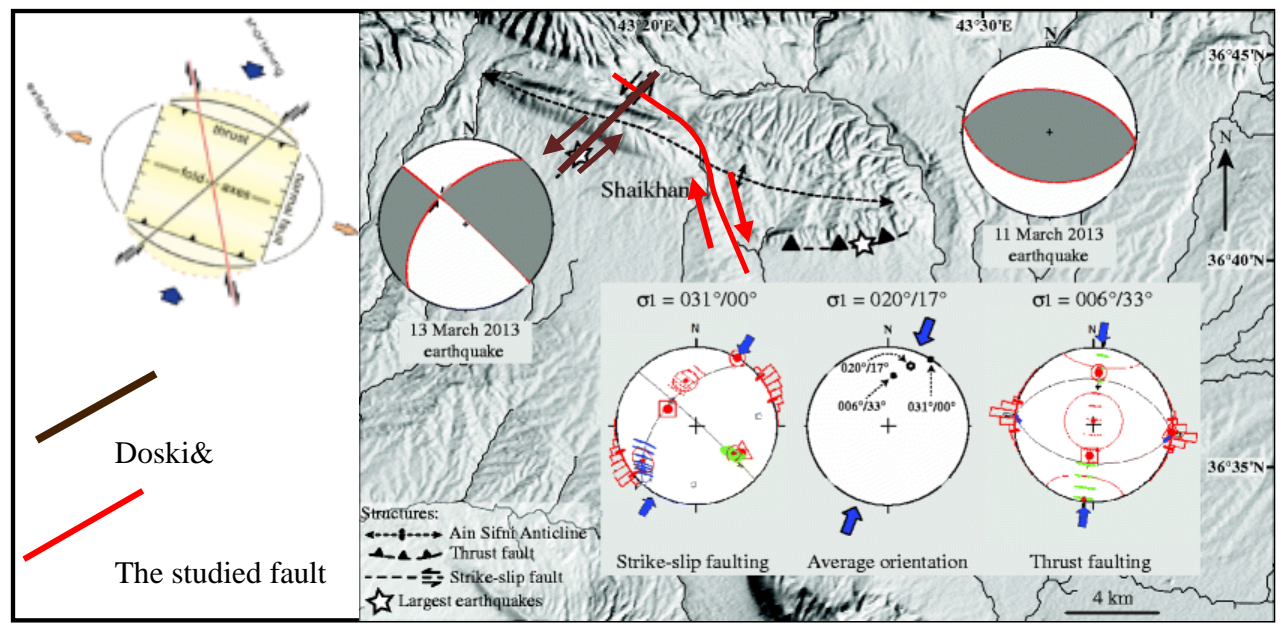

Fig. 7. The main fault of the study area in relation to other faults, (Doski \& Mohammad, 2016)

Thus, the fault is a dextral strike-slip conjugated with the northeast-trending sinistral strike-slip fault which is documented by (Doski and Mohammad, 2016) (Fig.7). It refers to a tectonic status causing transpressional structure, in particular, the vergency of the western part of the anticline is toward the northeast direction and compatible with the right-lateral displacement of the fault, while the vergency at the eastern part of the anticline is toward the southwest and corresponds with reactivated a steep north-dipping thrust fault inferred by (Doski and Mohammad, 2016) through analyses of Shaikhan earthquakes in 2013. The multi-displacements caused a high deviation of the fold axis towards the south in the area of the southeastern plunge.

\subsection{The Model of the Water Gap and Wind (Air) Gap}

A water gap is defined as an opening or passage through a certain barrier or active structure formed by a watercourse, whereas a wind or air gap valley is defined as an empty incise in the barrier that started as a water gap (Keller \& Pinter, 2002). Such valleys occur through the development of the lateral propagation of the active folds, as well as other evidence such as the low drainage density, degree of the dissected fold surface, appearance of new forms of drainage patterns, and deformation of the most recent sediments. These criteria were taken into consideration as a measure of lateral growth of the anticline, (Jackson et al., 1996). The formation of both two types of valleys is deemed a significant indicator of fold growth. Due to the tectonic movements and lateral growth of the folds, the water gap migrates toward the plunge zone and eventually changes to the wind gap form. Ain Sifni anticline contains two models of valleys; they are water gap and wind gap models. In the middle of the anticline, a wind gap has evolved from a water gap due to the growth and tectonic uplift of the anticline. The identified wind gap valley has been recognized by the visual interpretation and the profile drawn parallel to the fold axis. The topographical height of the identified wind gap valley is relatively higher than the newly formed water gap valley on the fold plunge. Keller and Pinter (Keller and Pinter, 2002) suggested this fashion demonstrate the relationship between the tectonic uplift and lateral fold growth, (Fig. 8).

As mentioned earlier, the water gap valley is located on the southeastern plunge of the anticline, and it has been distinguished from the lateral profile parallel to the fold axis, (Fig. 8). This valley is relatively low in elevation as compared with the wind gap valley, which indicates that it is a newly formed incision and has not been affected by the tectonic growth of the anticline (Bordal, 2014), whereas the wind gap valley has been sufficiently influenced by the tectonic growth, (Fig. 8). 


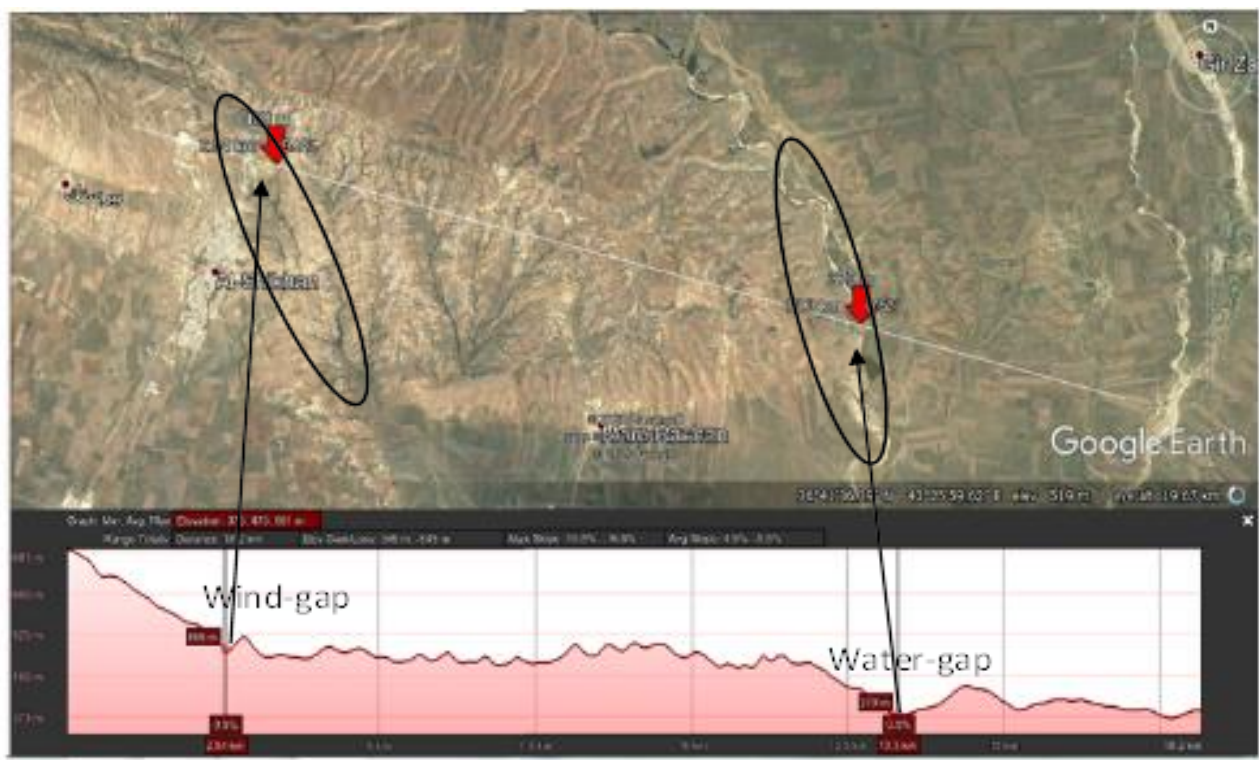

Fig. 8. Lateral profile showing the uplifted wind gap valley within the anticline

deformed due to the lateral tectonic propagation of the anticline. With the continuity of the lateral growth, the small drainage pattern may convert to another water gap valley (Fig. 9). Consequently, the previous water gap valley can transform into a wind gap valley (Al-Kubaisi and Abdul Jabbar, 2015). The fact that more than one wind gap or valleys of wind and water gap (for the same river) is a strong indication of the lateral propagation of anticlines (Keller et al., 1999; Ramsey et al., 2008).

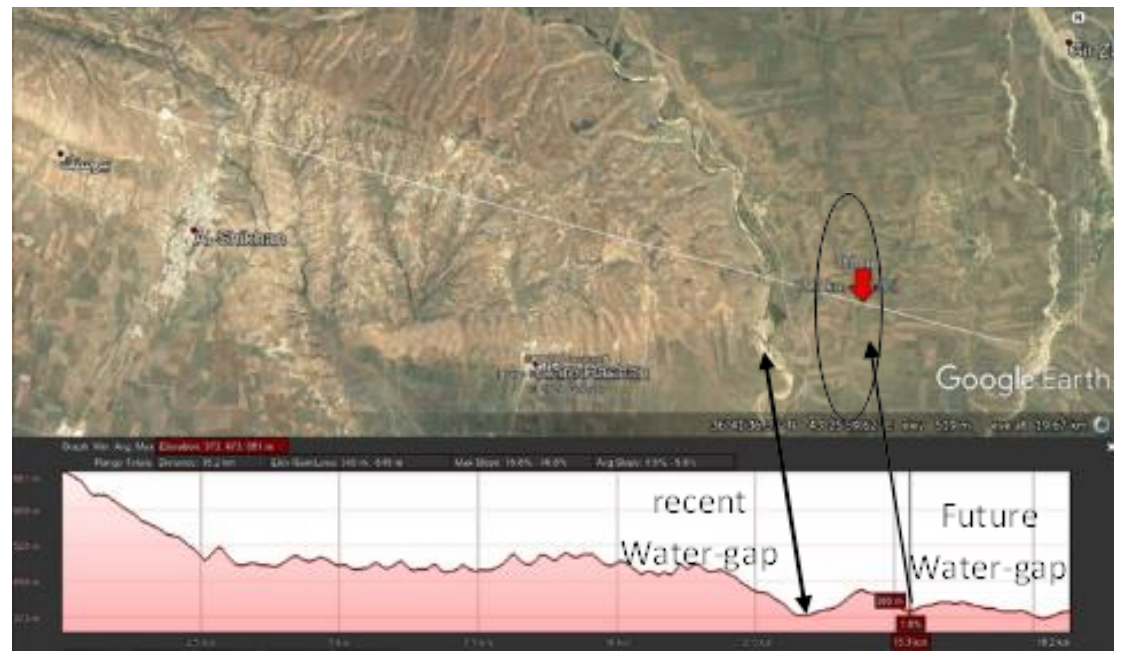

Fig. 9. Lateral profile showing the new water gap valley within the anticline

Ain Sifni anticline is relatively characterized by different morphotectonic phenomena from any other anticlinal structures. The eastern part of the fold is significantly different from the western part with the disappearance of its features due to erosion, tectonic growth, and the impact of the main fault on the anticline. The Principal Components Analyses (PCA) of a satellite image (Landsat) have been used. A false-color image has been setup by integrating the first and second principal components using Hue, 
Saturation, and Intensity (HSI) options in ILWIS 3.7software. This image helped to distinguish the rock units in the study area, particularly the Bai Hasan, Mukdadiya, Injana, and Pila Spi formations (Fig. 10).

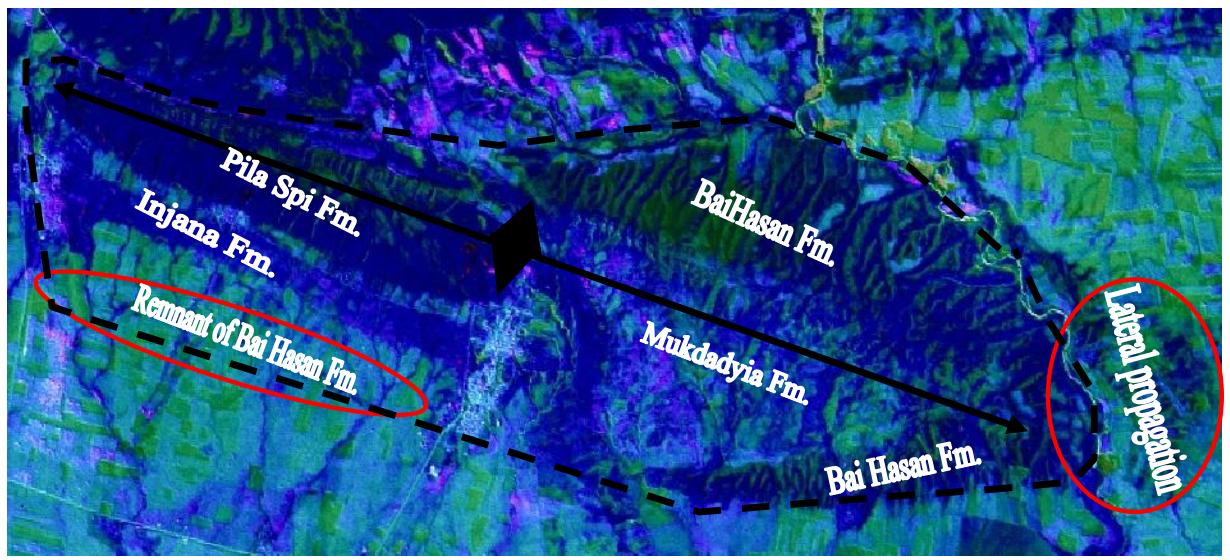

Fig. 10. False color image of the study area using the PCA method

The Remnants of the Bai Hasan Formation at the southwestern limb (Fig. 10) were identified as individual structural ridges affecting the drainage pattern. It indicates that these ridges are relatively harder than older rock units in the eastern part of the anticline, and suggesting that the anticline extends far from what can be seen in satellite images (Fig. 11). Through a standard visual interpretation of the satellite image, the southeastern plunge of the anticline ends up at the Al-Goumel River (Fig. 11A). While in the DEM, the anticline crosses the river eastwards (Fig. 11B). It represents strong evidence of the lateral growth of the anticline in the direction marked above. This can also be seen in the DEM of the study area through the existence of a relatively high region compared to the southeastern plunge, indicating lateral growth of the anticline (Fig. 11B).
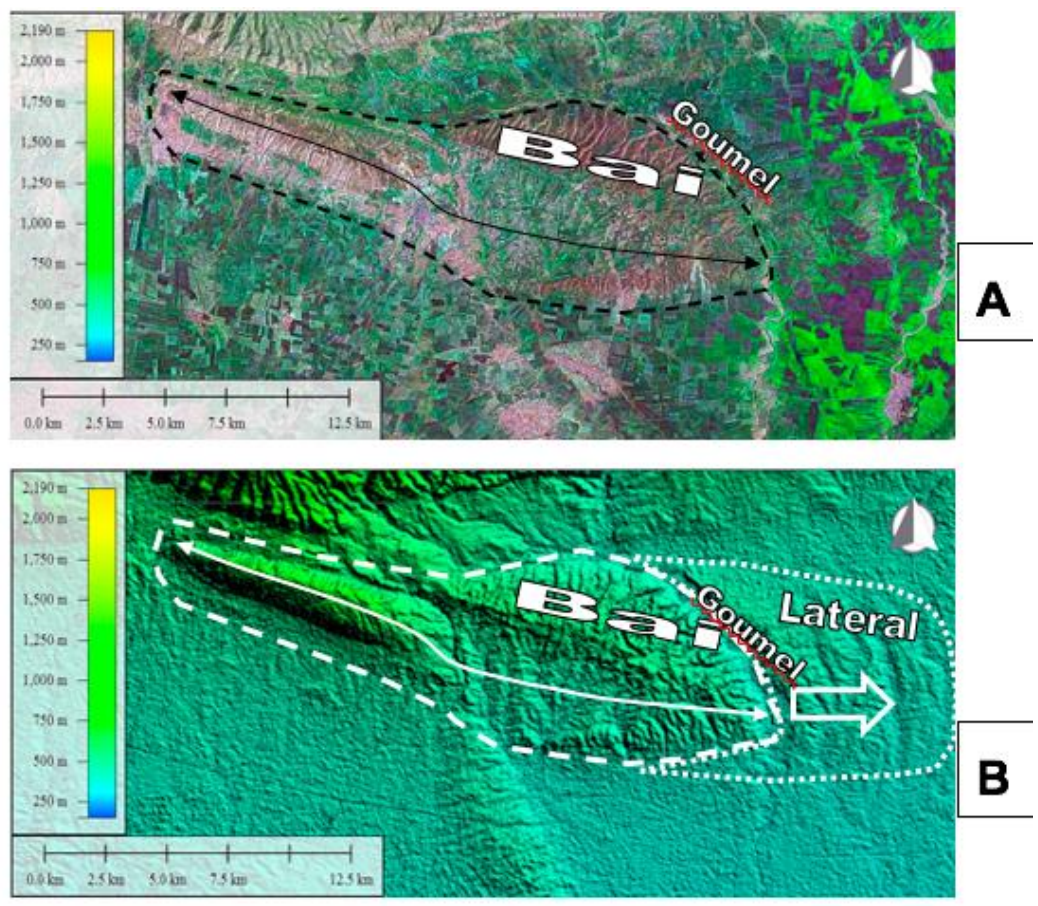

Fig. 11. Satellite image (A) with a DEM (B) of the study area 
At the northwestern part of the anticline, a group of cross-fractures on the fold axis has extended in a manner compatible with the tangential regional stress due to the left turn of the transverse fault (Fig. 12). Such faults are found in the anticlinal structures of certain regions around the world, including the inclined or wrench faults, as well as the faults on either side of the fold, (De Sitter, 1964). The case of the main fault concluded in this study has corresponded to the case of the cross-fractures.

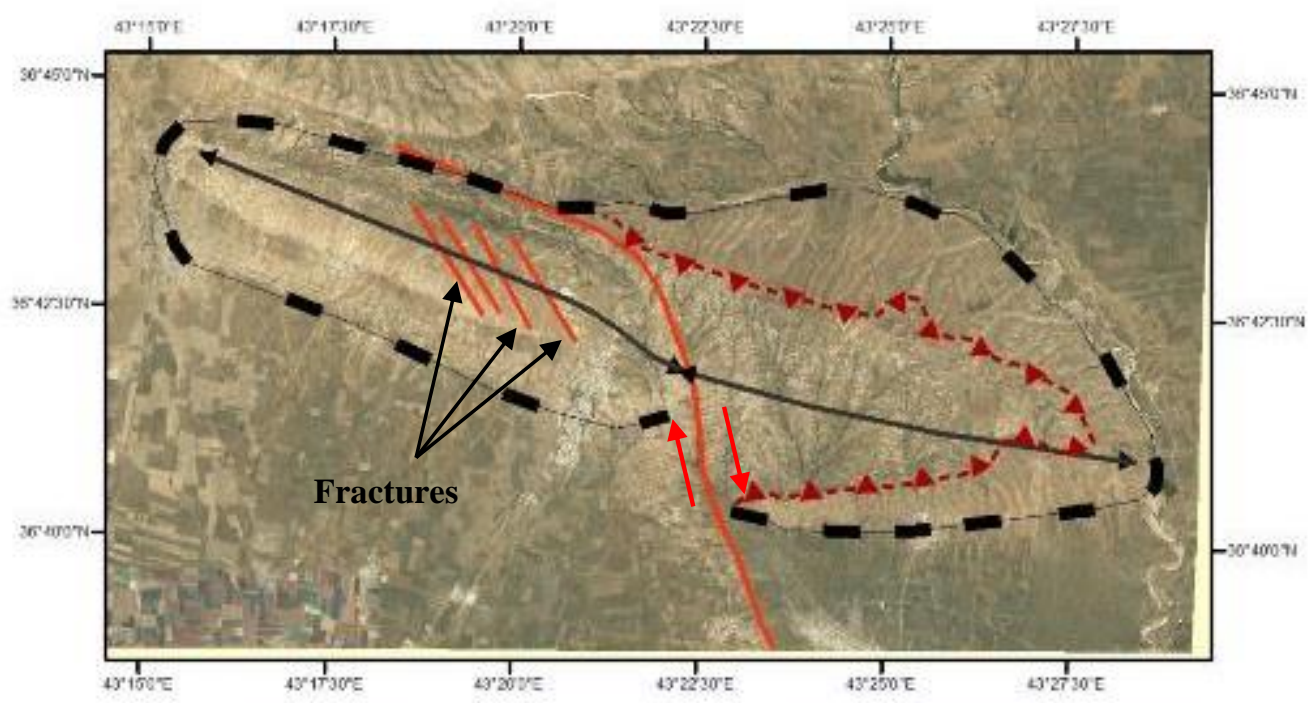

Fig. 12. Satellite image showing the group of cross-fracture in the core of the anticline (Pila Spi)

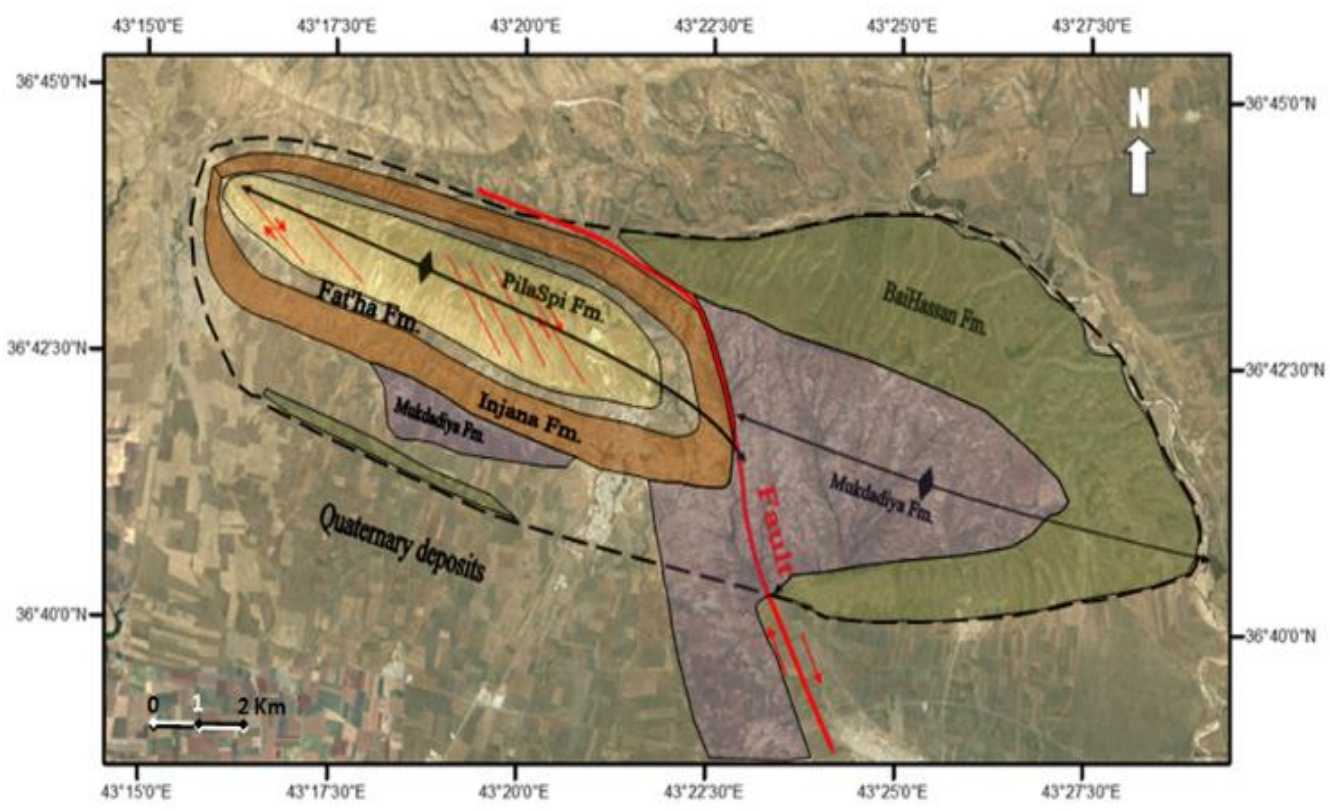

Fig.13. A geological map of the study area showing the shape of the anticline and cross-fault

\section{Conclusions}

The following findings have been obtained by combining the explanations and analyzes of the study area:

- The Ain Sifni anticline has been profoundly affected by a major fault transversal to the fold trend. As a result of the displacement and deformation of the rock units due to the fault, it has been defined as a left bent dextral strike-slip fault, therefore, Ain Sifni anticline may be considered as a transpressional fold structure (Fig. 13). 
- The clear existence of water gap and wind gap valleys, suggests a persistent neotectonics activity in this anticline.

- The eastern part of the anticline varies from that of the western part due to several interfering factors, such as the strong effect of the sliding through the dextral strike-slip fault that contributed to the uplifting and erosion of the western part of the anticline. Also, active water erosion plays an important role in forming the water gap and converts it into the wind gap.

- The existence of the fold lateral growth towards the east, southeast, and at the southeastern plunge, confirmed by the morphotectonic analysis of water gap and wind gap valleys, and by the uplifted areas that cross the Al-Goumel River at the southeastern plunge area.

- The core of the anticline that consisted mainly of the Pila Spi Formation has been affected by a group of cross-fractures. This is detected through the fusiform shape of the core, which implies the existence of a specific tectonic environment due to the strike-slip fault.

- The direction change in the fold vergency along the fold axis indicates that the anticline has influenced by the major strike-slip fault that cuts the anticline. The difference in the vergency of the anticline across the fault supports the mechanism of the right-lateral displacement.

- The morphotectonic analysis leads to conclude that the mechanism of folding amplification induced by the influence of the shear stress of the dextral strike-slip fault more than by pure shear stress, which indicates that the fault might be acted contemporaneously.

\section{Acknowledgements}

The authors of this paper would like to express their gratitude to the Mosul University, Mosul, Iraq for their support in completing this work. Also, we would like to thank the Remote Sensing Center, Dams and Water Resources Research Center, College of Science-Department of Geology, and the University of Mosul for their facilities, which have helped to improve the quality of this work. The authors are very grateful to the Editor in Chief Prof. Dr. Salih M. Awadh, the Secretary of Journal Mr. Samir R. Hijab. and the Technical Editors for their great efforts and valuable comments.

\section{References}

Al-Kubaisi, M. S., Abdul Jabbar, M. F., 2015. Effect of lateral propagation of selected folds on streams, Sulaymaniyah area, NE Iraq. Iraqi Bulletin of Geology and Mining, 11(1), 95-124.

Al-Kubaisi, M. S., Shakir M. M., 2018. Structural analysis for the plunge areas of Bekhair, Brifca, Dohuk, and Zawita anticlines northern Iraq using seismic sections. Iraqi Geological Journal, 51(1), 56-68.

Alvarez, W., 1999, Drainage on evolving fold-thrust belts: a study of transverse canyons in the Apennines: Basin Research, 11, 267-284.

Bordal, M. G., 2014. Drainage Reversals Due to Tectonic Uplift: An Investigation through Modeling, University Honors Theses, Portland State University, Paper 95.

Bretis, B., Bartl, N., Grasemann, B., 2011. Lateral fold growth and linkage in the Zagros fold and thrust belt (Kurdistan, NE Iraq). Basin Research, 23, 615-630.

Burbank, D.W., Anderson, R.S., 2001. Tectonic Geomorphology. Blackwell Science Malden, MA, USA.

Burbank, D.W., Pinter, N., 1999. Landscape evolution: The interactions of tectonics and surface processes. Basin Research, 11, 1-6.

Castelltort, S., Simpson, G. 2006. River spacing and drainage network growth in widening mountain ranges. Basin Research, 18(3), 267-276.

Collignon, M., Yamato, P., Castelltort, S., Kaus, B., 2016. Modeling of wind gap formation and development of sedimentary basins during fold growth: Application to the Zagros Fold Belt, Iran. Earth Surface Processes and Landforms, Wiley, 41(11), 1521-1535. 
Cotton, Ch., 1942. Geomorphology. $1^{\text {st }}$ Edition. Whitcombe and Tombs Limited, 505pp.

De Sitter, L. U., 1964. Structural Geology.2 $2^{\text {nd }}$ Edition, McGraw-Hill, New York, 551pp.

Doski, J.A.H., Mohammad, R.J., 2016. Tectonic analysis of the Shaikhan earthquakes, Kurdistan, northern Iraq. Arabian Journal of Geosciences, 9 (1), 16.

Geosurv, 1995. Geological Map of Iraq (Al- Mosul Quarter NJ - 38-13), 1; 250000, $1^{\text {st }}$ Edition, State Establishment of Geological Survey and Mining, Baghdad, Iraq

Grasemann, B., Schmalholz, S.,a 2012. Lateral fold growth and fold linkage. Geology, 40(11), 1039-1042.

Jackson, J., Norris, R., Youngson, J., 1996. The structural evolution of active fault and fold systems in central Otago, New Zealand: Evidence revealed by drainage patterns. Journal of Structural Geology, 18, $217-234$.

Jassim, S. Z., Goff, T., 2006. Geology of Iraq. Published by Dolin, Prague and Moravian Museum, Brno, 341pp.

Keller, E. A., Pinter, N., 2002. Active Tectonics: Earthquakes, Uplift, and Landscape. $2^{\text {nd }}$ Edition. Prentice-Hall, Inc., 362pp.

Keller, E. A., Gurrola, L., Tierney, T. E., 1999. Geomorphic criteria to determine direction of lateral propagation of reverse faulting and folding. Geology, 27(6), 515-518.

Ramsey, L. A., Walker, R. T., Jackson, J., 2008. Fold evolution and drainage development in the Zagros Mountains of Fars province, southeast Iran. Basin Research, 20, 23-48.

Sissakian, V. K., Abdulhaq, H. A., Ghafur, A. A., Omer H. O., 2020. Deducing the lateral growth of Handreen, Zozik, and Tanoun anticlines in Kurdistan Region using geomorphological features. Iraqi Geological Journal, 53(1C), 1-20.

Tomkin, J. H., Braun, J., 1999. Simple models of drainage reorganization on a tectonically active ridge system. New Zealand. Journal of Geology and Geophysics, 42(1), 1-10. 